\title{
Living with Precarious Legal Status in Canada: Implications for the Well- Being of Children and Families
}

\author{
Judith K. Bernhard
}

Ryerson University

\section{Luin Goldring}

York University

\section{Julie Young}

York University

\section{Carolina Berinstein}

Access Alliance Multicultural Community Health Centre

\section{Beth Wilson}

Community Social Planning Council of Toronto

\section{digital.library.ryerson.ca/object/168}

\section{Please Cite:}

Bernhard, J. K., Goldring, L., Young, J., Berinstein, C., \& Wilson, B. (2007).

Living with precarious legal status in Canada: Implications for the well-being of children and families. Refuge: Canada's Journal on Refugees, 24(2), 101-114.

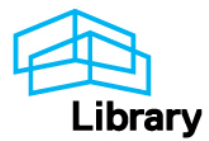




\title{
Living with Precarious Legal Status in Canada: Implications for the Well-Being of Children and Families
}

\author{
Judith K. Bernhard, Luin Goldring, Julie Young, \\ Carolina Berinstein, and Beth Wilson
}

\begin{abstract}
This study focused on the effects of precarious status on the well-being of fifteen participants with particular attention to their attempts to claim services, their feelings of belonging and sense of social support, and the effects of parents' status on children. It investigates ways in which the status of one family member can affect the well-being of the entire family. Those who had children reported that the family's status disadvantaged their children, whether they were Canadian or foreign-born, as parents' status was used to justify denying children rights to which they are entitled by international, national, and provincial laws. The paper challenges approaches to citizenship and immigration status that fail to consider the implications of legal status for a person's primary social units and networks.
\end{abstract}

\section{Résumé}

Cette étude examine les conséquences du statut précaire sur le bien-être de 15 participants, en se penchant tout particulièrement sur leurs efforts pour revendiquer l'accès aux services, leurs sentiments d'appartenance et de soutien social, ainsi que les répercussions du statut des parents sur leurs enfants. Elle examine les différentes façons par lesquelles le statut d'un membre de la famille peut affecter le bien-être de la famille toute entière. Ceux ayant des enfants ont rapporté que ces derniers, qu'ils soient nés au Canada ou à l'étranger, avaient été défavorisés par le statut de la famille, étant donné que le statut des parents était employé pour justifier le déni aux enfants de droits qui étaient les leurs en droit international et selon les lois nationales et provinciales. L'article remet en question les façons d'aborder la question de statut de citoyenneté et d'immigrant qui ne prennent pas en ligne de compte les conséquences du statut juridique sur les unités sociales de base et les réseaux sociaux pour chaque personne.

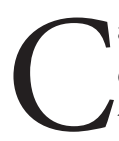

anadian citizens, secure in their full legal status, often take for granted many of the rights and entitlements that citizenship bestows on them. However, for other members of the population including, for example, non-citizen or not-yet-citizen refugees and immigrants, the question of status and thus of rights and entitlements is much less certain. ${ }^{1}$ In some cases, even citizens may encounter difficulty in accessing and obtaining services and protections to which they are entitled by virtue of their citizenship. This latter situation is not uncommon, for example, among Canadian-born children whose parents have uncertain legal status. Although recognized as citizens by birth, they may face barriers in accessing education and other entitlements. Drawing on qualitative data from fifteen interviews, this paper looks at the experience of precarious legal status for families and children in Canada.2 In particular, it investigates various ways in which the uncertain legal status of one or more family members can affect the well-being of the family as a whole, including Canadian citizens. Our approach challenges perspectives on citizenship and legal status that privilege the status of individuals in their definitions, and which fail to consider the implications of status for a person's primary social units and networks. 


\section{Key Concepts: Status and Well-Being}

Berinstein, McDonald, Nyers, Wright, and Zeheri and the Status Campaign used the term "non-status" to refer generally to individuals who do not have the required permissions or documents that would establish their legal and undeniable right to live and work in Canada on a temporary or permanent basis. ${ }^{3}$ However, we use the term "uncertain status" and also follow Goldring, Berinstein, and Bernhard's use of "precarious status" in order to stress that the question of one's legal position in the country-and hence the question of one's rights, entitlements, access to services, obligations, responsibilities, and so on-cannot always be determined as a strictly black-and-white matter. ${ }^{4}$ People may shift between statuses, and there are a number of grey areas to consider, which Goldring et al. refer to as "gradations of status." ${ }^{\prime 5}$ For the purposes of our study, the concept of precarious status is applied to individuals in a range of categories, who may also experience shifts between different types of legal status over the duration of their presence in Canada. ${ }^{6}$ Factors such as gender, ethnicity, class background, racialization, employment status, income, life cycle, age, and presence of young children are known to affect people's well-being. We add uncertain status as an important determinant of well-being.

Well-being refers not only to mental and physical health, but also to an individual's level of social and economic security. The conditions surrounding immigrant settlement, including immigrant status, are crucial to newcomer well-being. In her work with asylum seekers in Australia, Rees defined well-being as "a holistic state that includes psychological, physical, spiritual, social and cultural contentment and welfare...that incorporates both a public/social standard, as well as a personal/private viewpoint."7 Rees's definition is not only relevant to cases of uncertain legal status, but is typical of work that considers human health from a broad, "social determinants of health" perspective. ${ }^{8}$ Such an approach emphasizes the impact of poverty and inequality on health and on well-being, and it recognizes that there are also gendered and ethnoracial dimensions to these conditions. ${ }^{9}$ Well-being, in sum, reflects the individual's ability to function in and adapt to the new society.

Well-being is a key factor in settlement, playing a role in both adaptation and integration. A variety of experiences and factors before, during, and after migration contribute to individual and family well-being. There is growing recognition that "geopolitical, economic and cultural influences affect the health of immigrants." 10 According to Beiser and Hou, the main challenges to well-being during the settlement process include economic factors such as unemployment or underemployment, discrimination, and language barriers. ${ }^{11}$ Another significant challenge to wellbeing in the context of the settlement process is seeking a sense of belonging and welcome in the society of which one is now a part, as well as feeling valued and respected by members of that society. ${ }^{12}$ This would include a sense of one's ethnoracial and religious identity, and feeling oneself to be a member of a community - in the host country, one's native country, and/or a transnational community. ${ }^{13}$

In countries such as Canada, where public services provide education and health care to the population, being able to access social services is crucial to well-being. Several Canadian reports provided important insights for our study, particularly in highlighting the existence of a population living with uncertain status in Canada and raising questions about their access to services. ${ }^{14}$ The report by Berinstein et al., for example, drew attention to the fear experienced by non-status persons and pointed in particular to the vulnerability of non-status women to domestic violence. ${ }^{15}$ They discussed impacts on health including incidents of depression and documented lack of access to various services often because of the extreme demands of job situations. Challenges also arise from restrictions on labour market participation and mobility, as well as from lack of access to a range of services. Several researchers have identified fear as a barrier to obtaining services, and in particular have found negative outcomes in the areas of health and education due to this fear. ${ }^{16}$ Families with uncertain status who have children must make difficult choices with respect to livelihood in order to be able to care for their children. All of these factors cause many families to feel insecure and unwelcome, and this state of limbo results in precarious settlement.

\section{Research on Precarious Status in Canada}

The general topic of living without full legal status in Canada, and the specific study of families with uncertain or precarious status in Canada have remained under-researched for many reasons, including the inherent difficulties of working with "invisible" people, many of whom wish to stay below the radar of government authorities. ${ }^{17}$ Beyond the methodological challenges of establishing trust with people who are in precarious situations, the requirements of university ethics committees to protect the identities of these people can present serious obstacles to researchers, who may not conduct follow-up research, as that would involve retaining contact information. A major concern of such committees is the extent to which researchers might be compelled to provide information about participants to authorities. $^{18}$

Nevertheless, there is growing interest in the topic, spurred in part by a series of arrests and deportations that 
took place during the summer of 2006, which shed light on a topic that has received sporadic media attention. ${ }^{19}$ In the US, the Census Bureau ${ }^{20}$ has been counting and providing estimates of the undocumented population since the early 1980s, and academics have studied undocumented migrants from a number of disciplines and perspectives. ${ }^{21}$ However, in Canada there are no official statistics on the population with uncertain status, and available research on the topic, while important, is scarce. ${ }^{22}$

In the US, as in Canada, undocumented families experience significant challenges in terms of limited access to and differential outcomes in education and health. ${ }^{23}$ While the Canadian context is different from the more well-studied US case, findings from studies of the undocumented in general, and families in particular, provide an important literature and should inform Canadian research. A recurrent theme in this work is that undocumented or uncertain status compounds other forms of exclusion and marginality, making it difficult for those without full status to experience well-being. At the same time, the presence of a large undocumented population can mitigate the effects of individual undocumented status.

In his work with undocumented Mexicans and Central Americans in San Diego and Dallas, Chavez examined the multiple understandings of one's sense of community, noting that it may be "imagined" and not confined to a specific geographic area. Ideally, suggested Chavez, migrants, even though undocumented, come to have "a sense of belonging to multiple communities." ${ }^{24}$ In his sample, 60 per cent of Mexicans and 50 per cent of Central Americans felt they were a part of their American community. For these individuals, a sense of community came from shopping, having friends, and participating in community events including church functions. Chavez underscored the fact that for most of these people, feeling a sense of belonging to their American community was separate from other feelings of severed ties with the "home" community. His regression analysis yielded some important correlates of belonging, for instance, residing in the US for more than three years, higher family income, and intention to stay permanently.

However, contrasting findings were reported by Rees in her qualitative study of East Timorese women asylum seekers in Australia. She found their sense of well-being to be "dangerously compromised." Some had been tortured or traumatized in East Timor and their difficulties during the asylum-seeking process can be considered re-traumatization. Rees quoted a typical informant as stating that the several years of waiting for a decision on their case had an effect, which was "absolutely overwhelmingly enormous. Many people are becoming mentally ill or having total breakdown." ${ }^{25}$ She mentioned such factors contributing to the lack of well-being of the participants as access to medical care and access to post-secondary education.

Menjivar's studies of Salvadoran and Guatemalan immigrants of uncertain legal status in the US presented similar disturbing findings. She particularly stressed the all-pervasive effects of long-term uncertainty about one's legal status. She proposed the concept of "liminal legality" to capture the ambiguity between documented and undocumented status that she has observed in research she conducted between 1989 and 2001. For many of her participants, their existence in the US was "a condition of permanent temporariness." ${ }^{26}$

\section{Impacts on Children}

Parents' immigration status often disadvantages their children even if these are native-born. ${ }^{27}$ This calls into question the mainstream assumption that citizenship or legal status operates at the level of the individual, describing citizenship (or - by extension - lack thereof) as a status conferred on individuals by the state or a relationship between an individual and a polity. ${ }^{28}$ While feminist and other scholars have critiqued Marshall's classic formulation, citizenship theorists have been largely silent on the issue of children, as childhood has been seen as a transitory status on the way to adulthood and citizenship. ${ }^{29}$ While limited, existing research on children and legal status points to the importance of considering the impact of parents' status on the entire primary social unit.

Young's study of youth living with uncertain status in Toronto explored how they experienced their legal status, particularly its impact on their feelings of belonging and their ability to have agency. She found that youth with limited status were trying to participate and lead "normal" lives but found themselves in a position of having to constantly negotiate their status and explain why they did not have key documents such as health cards. Although at times they could be with their friends and try to forget about their status, they also indicated that they felt like outsiders who did not belong and worried about their own and their family's futures. ${ }^{30}$

In the US, the five-year Longitudinal Immigrant Student Adaptation (LISA) study carried out by Suarez-Orozco and Suarez-Orozco looked at immigrant youth's academic engagement and outcomes and made a point of noting which participants were undocumented. ${ }^{31}$ Parents and children living in this situation viewed teachers, nurses, police officers, and other authority figures with distrust and fear, and worried that they could be detained and deported at any moment. The researchers reported that many of the children they interviewed felt "constantly hunted" or worried that if one of them was detained, "they will never be reunited with their parent."32 
It is worth looking in more detail at the specific effects of parents who decline to register their children for school or health-care access. ${ }^{33}$ Parents are often fearful of revealing their status to authorities. In Toronto, families with uncertain status are not eligible for subsidized childcare and the cost of child care is prohibitive to many families, even those with full legal status. ${ }^{34}$ In addition, they are ineligible to receive the Canada Child Tax Benefit that is in place to support families with children under age eighteen. ${ }^{35}$ Bernhard et al. found that this lack of access to services for children placed a strain on mothers with uncertain status who were often hesitant to even find out whether they were eligible for various services. Crucially, the high cost of child care influenced some mothers' decisions to send their children to be cared for by relatives in the home country for a time, which was a source of shame both while they were separated and once they were reunited. ${ }^{36}$

Of particular relevance to the present paper are US attempts to prevent undocumented parents from benefiting from their US-born children's citizenship status, with some policy makers and lobbyists calling for the abolition of birthright citizenship which is currently constitutionally enshrined. Fix and Zimmermann point out that implementing such legislation would bring hardship to both the families and citizen children involved as their rights may be affected by restricting their access to services or, in some cases, by their even being forced to leave the country. ${ }^{37}$ Children born in Canada to parents with uncertain status have been deported along with their parents. ${ }^{38}$

The present study focuses on the effects of precarious status on well-being with particular attention to factors including access to education, health care, settlement services, and housing. We address the following three topics and associated research questions: (1) Attempts to claim services. What discrepancies are there between the services that persons with precarious status are actually able to access and those to which they and their children are legally entitled? How does this gap affect well-being? (2) Feelings of belonging and sense of social support. To what extent does the uncertain status of parents affect their well-being, specifically their sense of belonging to a community and their hopes for themselves and their children? What are the negative effects on emotions? (3) Effects of parents' status on children. To what extent does the uncertain status of one or both parents limit the ability of children, including Canadian-born citizen children, to access the services to which they have rights? What impact does this limitation have on the children's well-being?

\section{Method and Sample}

The findings reported in this paper emerged from a mixedmethod pilot study. The study, the most recent collaboration by a team of researchers that has worked together for several years on issues relating to immigrants and refugees in Canada, focused on fifteen individuals (twelve females and three males) living with precarious legal status in Toronto. In addition, a telephone survey of sixty-two agencies serving newcomers was also conducted to ascertain the extent to which agencies restricted services due to legal status. ${ }^{39}$ The study of the fifteen individuals consisted of a semi-structured interview protocol that was administered in the language with which the participants were most comfortable. We sought to ensure the validity and authenticity of the data by using interviewers who were fluent in the native languages of the interviewees as well as familiar with the cultures involved. The languages represented in the study were: English (three participants); French (two); Spanish (five); Portuguese (two); and Tamil (three).

The interview guide included questions in the following areas: socio-economic profile; participants' migration and status histories; social networks; and use of services. The open-ended interview questions provided participants with an opportunity to discuss their experiences, particularly barriers faced when accessing services, in greater detail. The interviews were audio-recorded and transcribed, and lasted between forty-five minutes and two hours. Participants received a Canadian $\$ 50.00$ honorarium as compensation for their time and participation.

In order to maintain the confidentiality of participants, interviewers and researchers were not permitted to record participants' names or contact information. A number of additional measures were taken to preserve the confidentiality of information and ensure that the participants had all the benefits of a research process that conformed to the university's research ethics review process. ${ }^{40}$ Communitybased workers and researchers from front-line service-providing organizations that work with individuals and families with uncertain status (including health-care centres, legal clinics, and settlement agencies) recruited participants; consequently, the sample was not random. Reliance on community organizations as points of entry limited the selection of participants to clients of those organizations who were available for interviews during the working hours of the organizations. The sample did not include individuals who have never sought help at an organization and who may be quite isolated. 


\section{Profile of the Respondents}

The fifteen participants represented a broad range in terms of country of birth, age, ethnoracial background, and education. Three respondents were from Sri Lanka, two each were from Brazil, Costa Rica, the Democratic Republic of Congo, Grenada, and Mexico, one was from Chile, and one from St. Vincent. The respondents ranged in age from 23 to 64; four were between 21 and 30 years of age, five were $31-40$, four were 41 to 50 , and one was over the age of 61 . Just under half of the respondents (seven) had some high school education or had graduated from high school. Six had some college or university (four) or trade certification (two), and two respondents were university graduates.

Data on marital status and parenthood did not present surprises, although the proportion of single respondents (46.6 per cent) was high. One-third (five) lived with a spouse or partner, two were widowed, and one was divorced. Two-thirds of the respondents (ten) had children. Of these, one respondent had six children, the others had from one to three, for a total of twenty-three children.

The children's place of birth and current location combined to create cases of mixed-status families and geographically dispersed families. Half of the respondents with children (five) had children who were all born outside of Canada; two respondents had children who were all born in Canada; three had children of whom some were born in Canada and some abroad. That is, five adult respondents with less than full status had at least one child born in Canada, placing one-half of those with children in the category of mixed-status families (or one-third of the total sample). Furthermore, the current location of children was not always the same as their place of birth. Thirteen of the children, belonging to seven respondents, were living in Canada, while ten children were living abroad. More specifically, six respondents had children born outside of Canada who were living with them in this country (accounting for nine children), ${ }^{41}$ four had Canadian-born children with whom they lived in Canada (four children), three had children born outside of Canada who were not living with them (seven children). ${ }^{42}$ Three respondents had children living outside of Canada, and two of these also had a Canadian-born child living with them in the country.

In terms of migration history, it was the first time coming to Canada for ten of the individuals (two-thirds of the sample), while for five it was their second. Five (one-third) of the participants had been in the country with uncertain status for more than six years, three had been in Canada from four to six years, two from two to four years, four between one and two years, and one for less than one year. At the time of the project interviews, seven participants were awaiting the outcome of a Humanitarian and Com- passionate $(\mathrm{H} \& \mathrm{C})$ application or appeal, three were awaiting the outcome of a refugee claim, three were denied refugee claimants (one of whom had received a deportation order), and two had overstayed their visas. Despite the fact that the participants constitute a heterogeneous group, we suggest that there are similarities in their experiences because of their uncertain legal status.

\section{Findings}

\section{Finding One: Limited access to services due to} uncertain status affects the well-being of all family members.

Several participants spoke of their inability to access health care due to their uncertain status and lack of health coverage. Thus, they experienced barriers due to their lack of full status and/or documentation as well as financial constraints. For example, although Ms. Rodriguez ${ }^{43}$ and her family were eligible for limited health coverage under the Interim Federal Health Plan, it took three years for her husband to succeed in gaining medical attention:

Even though I tried to do everything they would tell me, even following the process, it took me three years to be able to find a doctor for my husband. So this was a very difficult time for him and for my son because it was all at the same time-the medical attention for my husband, the need to eat-but we managed. We would make the rounds going to the different shelters, stopping for coffee in one, eating in another, and we continued making stops like this, going from one place to another. And then, we would primarily look for my husband's medication. Then he was happy. The fact that we were here made him very happy. But we ended up dead tired, just dead.

Significantly, Ms. Williams revealed that she was turned away from a health clinic because of her lack of status:

They said to me, "You know what? You don't have full status. We are booked with non-status women." And I was pregnant, sick, nauseated, depressed-everything. And they told me, "You don't have status. You need to find another clinic. We don't have space."

Ms. Rodriguez spoke of the different treatment she experienced in attempting to access health care without full status and documents:

Yes, you see this is the problem. The health clinic is very good when one has papers; there is all the help in the world. But when one does not have papers, that is a totally different question. And, if you go once to the centre, you can't go back because then 
you are risking your status. In other words, you risk your ability to stay in the country.

In addition to the restrictions faced by individuals with uncertain status in receiving medical treatment, the cost of health care is prohibitive and is a significant barrier to accessing services for those people who are not covered by health insurance plans. Tellingly, Ms. Jackson indicated, "I'm praying not to get sick because it's very expensive and I don't have the money right now to go to the doctor."

A few participants spoke of being denied employment or having difficulty finding and keeping a job due to their lack of papers and status. For instance, Ms. Jackson found that "some places, they don't want to hire you because you don't have certain documents. It's really hard." Similarly, Ms. Williams was constantly asked for various documents when she was looking for work: "It's hard. When you go job searching, they ask 'Do you have a social insurance number, do you have a work permit, do you have...?' It's very hard for non-status. And not only non-status, women especially."

Mr. Raveendran indicated that he was regularly asked to show two pieces of identification, which he did not have, in situations ranging from when he attempted to open a bank account to when he tried to register for English as a Second Language classes. In addition, he felt that the document he was given to indicate his status as a refugee claimant was problematic:

We have no ID to give. When I filed the refugee claim, they gave me a big sheet. We cannot take that document everywhere. Hence, they should give us a small ID. They should definitely make a change regarding this. They should give a small document with an ID number on it to keep in our wallet. Because it is a big sheet, we cannot take it everywhere.

Several participants mentioned the high financial and emotional costs of the migration process, particularly in terms of figuring out applications, working with lawyers, and facing uncertainty. Ms. Williams pointed to the financial barriers that she experienced: "Because sometimes you don't have the money. Number two, to go to get help is another problem. Lawyers' fees are one problem." Similarly, Ms. Rodriguez revealed that her family did not even have money for the necessary bus fare as they attempted to navigate the immigration system on their own:

In order to be able to explain my husband's case and to be able to say what was happening to him - that was the worst. There were times when we'd spend hours looking for a bus transfer on the ground that was still valid so we could take the bus. And to think of the number of times we would get to a lawyer's office and they would say, "You don't qualify," or "Do you have your return ticket all in order?" We always left crying. And in many places they said to us, "You don't have a case." But even so, we persevered. We persevered and each day I would try harder and harder to find a place where they would give me good information.

The significant time spent on learning the legal intricacies of a complex system and having to constantly explain their eligibility for essential services took a high toll on the participants and their children.

Finding Two: Precarious status leads to pervasive feelings of fear and isolation.

Feelings of fear and isolation limit positive interaction for people with precarious status, limiting their interaction within their ethnoracial communitiesand in Canadian society more broadly. Moreover, the stress of uncertain status manifested itself in disturbing ways. In the case of Ms. Latouré, her husband became abusive:

At the beginning, I even tried to be among women who are victims of violence to join their support group. Because then, when my husband and I would begin to talk about this problem around the papers, he would get irritated. And when I would say something, or he would ask me for something and I did not do it right away, he would get irritated and he would come towards me to try to hit me. And the children would tell him, "No, daddy, you mustn't do that, because when you do that, the neighbours will call the police. We will have serious problems and our chance to get papers will be finished. Our file cannot have a police blot on it." So really he was very aggressive until he found a job, then he calmed down a bit. But when we started talking about the problem around the papers, then he started to act up again.

Some of the participants spoke of the social isolation they experienced due to their uncertain status. Mr. Raveendran revealed that he felt so separate even from his own ethnoracial community that he at times believed it would be better for people living with uncertain status not to interact with the larger society, or even their ethno-racial peers, until they had some documentation or official status:

We Tamil people are unable to show our identity. We're in a situation where we need to isolate ourselves. When we look at other families, those who lived here before look down upon those who came later. It's true. This is because they did everything officially. Hence, they continue to do everything. We are unable to do anything officially. That is the basic problem. If we 
were able to do everything officially, then we also could fight. This is a problem. Therefore, we should get all documents legally and quickly. If we get them, only then we can do it. So if not, until we get at least some document in the society we should not be permitted to mingle in society.

Ms. Bolaños expressed similar feelings of isolation on many levels:

And for this reason you become completely isolated from your community, from people, from everything. And it is because of the fear of being deported that we live with. One becomes totally isolated to the point that, I don't even go to the church where they speak my language ... it is because people will ask uncomfortable questions.

Significantly, Ms. Rodriguez spoke of not being able to speak about her situation and of not having a sense of security:

And if there is still work to do [available], it does not matter because you know that you may have to move to another city or another job at the moment when you least expect it. You do not have a sense of security around other people. You do not have that. You almost have to walk around without saying a word all the time. You can't comment on anything.

Ms. George outlined a vision of how she would like to participate and live in Canada, a vision that was limited by her immigration status: "Oh, it's so hard. I guess for the things that I want to do. I want to go to school. I want to have a good job that I can count on. I want to do so many things. I want to give back to the community, what they give to me, but it's too hard."

Mrs. Jackson vividly illustrated her fears:

Because sometimes you gotta be scared. I used to be scared a lot. Because true like other people telling me stuff, and you know that if Immigration tells you that you're gonna get deported, and stuff like that. So I used to be really scared! Sometimes I don't even want to go out and deal with all this stuff.

Finding Three: According to parents, the family's uncertain status had a strong impact on children in particular, both Canadian and foreign-born (raised in Canada).

It is important to remember that there are a number of special considerations that attach to the situations of children in families where one or both parents have uncertain status. Children themselves are entitled to a number of legal rights. Indeed, they are guaranteed a full range of rights under international-and consequently national and pro- vincial-laws. For instance, all children in Canada have the right to attend school regardless of their own or their parents' legal status. ${ }^{44}$ Moreover, the UN Convention on the Rights of the Child affirms that in all decisions affecting children, the best interests of the child must be primary. ${ }^{45}$

The children of the individuals who participated in this study were particularly affected by their families' precarious legal status. Ms. Bolaños spoke about the challenges her children faced at school and of not being in a position to seek help from school authorities due to the family's status. Other students bullied her children but she felt there was no recourse due to their status situation. In addition, the school identified that Ms. Bolaños daughter would benefit from seeing a speech pathologist, but that due to her legal status, they could not refer her to one:

The simple fact of seeing my children so isolated is incredibly painful. Now when they meet people, they are shy and withdrawn. Even in school my children have been abused in the sense that there are children who hit them. My daughter, for example, is a child who has trouble speaking. When she is very nervous, sometimes she can't speak at all. I was looking for a way to get her therapy. They told me that she needs a speech pathologist, but unfortunately they haven't been able to help her with this because of my legal situation.

Canada, as a signatory to the UN Convention on the Rights of the Child, is obligated to uphold the best interests of the child in all decisions that affect them regardless of their legal status. The school's inability to help Ms. Bolaños's daughter to access a speech pathologist due to her mother's legal status contravenes the spirit of the Convention.

Another challenge faced by the families in this study was that of overcoming their fear due to their status and registering their children in school, according to their right under international, national, and provincial legislation. It is important to reiterate that this right applies to Canadian-born and non-Canadian-born children alike. Ms. Ayala's family faced a peculiar situation while living with precarious status after she had overstayed a tourist visa: she had two children, the older born outside of Canada and the younger in the country. Interestingly the younger, Canadian-born child was not in child care (as the mother did not qualify for subsidized child-care rates due to her uncertain status), while the older, non-Canadian-born child was attending school. In this case, the younger child was experiencing the impact of her mother's status while the older one was successful in accessing her right to education regardless of her own and her mother's status. In addition, Ms. Ayala was unable to submit a claim for alimony from her former husband due to her status, a limitation that disadvantaged both of her children. 
In the case of Ms. Latouré, she was unhappy that her children would be unable to pursue post-secondary education due to the family's uncertain status in Canada. They were in high school and in two or three years would be ready for university; however, they would be considered international students and as a result would be required to pay much higher tuition fees than their peers. This cost would be a barrier for the family and the children would not be able to pursue their studies:

And even if my children are in school-they will soon be old enough to attend university - they won't go to university. This, this is what hurts me very deeply, again for my children.... Not to have papers in Canada, for me it's really, it's as if your life has been cut off. Because for me in any case...we have children, the children grow up, they have to study. Children are tomorrow's future.

Although the situation of these children would not likely fall under the terms of the UN Convention, as it applies to children up to age eighteen only, it is nonetheless problematic and disadvantages the children on the basis of their uncertain status, regardless of how long they may have lived and studied in the country.

Finally, the fear of their status being discovered may cause parents to limit their children's and their own interactions with people outside of the family. For example, Ms. Bolaños noticed that her children were quite shy and suggested that this could be due to their limited interactions with other children:

For example, my two children are very shy because they live only with their mother and father and are always at home. That's all we do. There is no comradeship so that they can say, "This weekend we are going to play with our friends, with the children of my father's friends." We don't have anything like that.

Five of the fifteen participants in the study had Canadian-born children. These women faced considerable challenges in accessing services on behalf of their children, especially services such as Ontario Health Insurance Plan (OHIP) coverage and health-care access to which these children were entitled as Canadian citizens. For instance, Ms. Jackson was a denied refugee claimant awaiting the outcome of a Federal Court Review and she had a seventeen-month old, Canadian-born daughter:

I find they give you a really hard time when you don't have status because, for instance, my daughter was born here and some things I can't get for her. For instance I can't get child tax benefits for her. I only get a year.... I have to renew her health card every year. And I find that that should not be. I find this very hard. Regardless of the parent's status, I find they should give the child what belongs to them because they were born here. That's what I find. I don't find they should take away the child's rights because of the parents.

Ms. Williams, who had a three-year old, Canadian-born son, found that her status had a negative impact on her ability to access services for him: she had been unable to get full OHIP coverage for him. She went on to speak more generally about the impact of the uncertain status of parents on Canadianborn children:

I believe that as a Canadian-born, a child should have access to everything. Whether a woman doesn't have status, or the father doesn't have status, or whatever, the child is a Canadian-born. They should have everything that is supposed to be for them. For example, you can't file for baby bonus for them because of status. You cannot file for childcare because of status. It's not really fair for the kids that because the mother and the father don't have status, they cannot have access. So it's really unfair. You know, because they have to survive as any other kid in this country.

In such cases, the parents' status means that their children could not benefit from the financial assistance of the child tax benefit or subsidized child care. For example, Ms. Williams's son was not in child care because of her uncertain status, her low income, and the high cost of programs:

For the money. You have to give the money but it's too much. Because I tried for him, and for one month, the cheapest childcare I got was $\$ 700$ dollars a month. And it's very hard for non-status who only take a job at a time....and, not only that, the little income they get is very hard too.

Ms. George's four-year-old, Canadian-born son was also not in child care and she could not afford to take him to other children's programs offered in the community:

I stayed home because I didn't have money to put him in childcare, and it was easier for me. That's the way that we grew up, that we take care of the babies for a certain time. It was kind of hard. There were programs that I wanted to take him to but I didn't have money, so I did it on my own.

Ms. George was deeply affected by not being able to provide adequately for her son:

There is one thing that I wanted to do, that was go to school and take care of the child's health care. And I needed a social insurance number for that. You can't have that, so right about there, I think my heart was broken. So I just gave up. 


\section{Discussion}

As our data demonstrate, the precarious status of one or two parents can have negative repercussions on the well-being of the entire family. The stresses reported were shared among all members of the families we interviewed. There were some families who felt isolated and had to deal with constantly being turned away or turned down by the organizations where they went to seek help. Some parents found that their children were shy and isolated and at times unable to receive services that other children are offered through the school. This is consistent with Young's findings of youth being constantly confronted by their precarious status and reminded that they were different from their friends ${ }^{46}$ Our findings also agree with those of Suarez-Orozco and Suarez-Orozco who observed fear and distrust of authority figures among the undocumented children and youth in their study. ${ }^{47}$

We found fifteen different experiences of uncertain legal status lived by the fifteen participants. Some were likely destined for eventual success in regularizing their legal status, as they had fewer legal hurdles to overcome than others in securing permanent residence for themselves and their families. Our findings demonstrate that if one member of a family does not have full legal status, all members will have limited rights and entitlements. They also lend support to non-binary conceptions of legal status such as Menjívar's "liminal legality" and Goldring, Berinstein, and Bernhard's "precarious status." 48 Regardless of their different pathways to uncertain status, the fact of being in a grey legal area and an unclear social situation dominates the accounts of the people we interviewed. In short, we found that living with precarious status had the "overwhelmingly enormous effect" reported by Rees. ${ }^{49}$

Regarding our first question about accessing services, common to the reports of most participants was the inability to access vital services, especially health care. Many of these difficulties occurred along with problems in finding employment. Consistent with earlier findings, participants in this study were often afraid to even ask about their eligibility for various services even when their children were Canadian-born. ${ }^{50}$ In our interviews with participants we were constantly reminded of the pervasive effects of instability and uncertainty in areas such as settlement, child care and education. "Normal" family life seemed to disappear in the constant struggle to survive.

Why are we hearing such reports when in the city of Toronto, for instance, there are dozens of community agencies that do not ask about their clients' legal status? Of the sixty-two agencies we surveyed during this project, most said they did ask about legal status and a majority (77 per cent) stated that they do not turn people away for any reason. ${ }^{51}$ The answer appears to be that a participant's chances of facing barriers even in potentially friendly agencies is quite high: this is related not to the presence or absence of goodwill toward people living with uncertain status at the level of an agency or worker but instead to restrictions on access to programs funded by government agencies. ${ }^{52}$ This raises the question of why clinics that do not ask any questions are not accessed by more people with precarious status? Further research is necessary to identify deficiencies in public awareness campaigns directed toward immigrant communities and the effects of funding constraints. We can state, however, based on our interviews, that fear of the authorities is apparently uppermost in the minds of these people. Perhaps if churches and settlement workers were provided with additional information, individuals living with uncertain status would be able to overcome their fears and seek support from appropriate community agencies.

On questions of the extent to which people with precarious status feel a sense of belonging and social support, our participants' described pervasive feelings of fear and isolation. This finding is consistent with work by Menjívar, Rees, and Wayland ${ }^{53}$ Uncertain status undermines one's ability to develop networks within both one's own community and the host society. One respondent, Ms. Bolaños, indicated she did not go to the church where they spoke her language because people would ask uncomfortable questions. We were surprised at the number of participants who felt separate even from their own ethnoracial, religious, or linguistic communities. It is often assumed that people living with precarious status derive benefits from established communities of their peers. The facts are not so simple. Mr. Raveendran spoke of those in the Tamil community who are already established and had done everything officially. These people, he said, "look down" on later arrivals so a person's official designation as legal or illegal has inescapable consequences even at the micro level of intracommunity interactions.

Regarding the extent to which the families' precarious status influenced the experiences of their children, we found that the participants in our study were not clear about their children's rights, and, as a result, children's entitlements were curtailed. Similar to Young's report, we found participants greatly affected by the lack of key documents, especially health cards. ${ }^{54}$ Two of the most glaring gaps had to do with children's access to medical services and education. The fact that in principle, the law establishes the rights of these children does not mean that in practice the law is working as intended. In simple terms, Canada has not succeeded in meeting its obligations to children. This study has found that there is a particular impact on children living in families with uncertain status despite the protections that ought to be afforded them under the UN Convention on the Rights of the Child. ${ }^{55}$ The absence of systematic data on people with un- 
certain status makes it difficult to estimate the magnitude of the problem, but there may be several thousand children in Canada who are not able to obtaining their basic rights under national and international law.

It is crucial to highlight here a group that is particularly disadvantaged: the Canadian-born children of individuals with uncertain status. Although these children are born in Canada and have rights as citizens, they seem to acquire their parents' precarious status rather than having their citizenship taken as their status. There experiences of the mixed-status families in our sample are consistent with Fix and Zimmerman's finding that the uncertain status of parents has, in their words, a "chilling" effect on the citizen children's use of benefits. All of these findings undermine the common belief among Canadians that the children of immigrants usually end up in a better situation than that of their parents. ${ }^{56}$

This pilot study has several limitations. Chief among them is the fact that the small sample we worked with may not be representative; however, our aim was to produce a qualitative research study that would be illustrative of a range of experiences and situations. Secondly, all of the participants we interviewed were living in Toronto. It is likely that individuals living with uncertain status in smaller Canadian cities or rural locations would have different experiences due to lower availability of services and less awareness of the presence of a population living with precarious legal status. Of course, it is also possible that in small communities residents ignore the uncertain status of long-time residents, or people who have fallen out of status-including workers who fill labour market needs.

\section{Conclusion}

The present study provides a glimpse of a social problem whose dimensions are largely unknown. The accurate enumeration of adults and children living with precarious legal status in Canada has not been carried out. We know of no coordinated efforts underway to improve the delivery of settlement, health, and education services to these individuals, especially to children. The funding restrictions under which many agencies work are likely to remain in place. Our general conclusion is that an unknown but not insignificant portion of the Canadian population, including vulnerable children, is accessing far fewer of the benefits available in Canadian society than they might reasonably expect. Further research is needed to establish the scope of this dimension of social exclusion.

A key finding of our research is that an individual's status has broader repercussions: parents' status in particular can contribute to barriers for children and seems to be used to justify denying children rights to which they are entitled by international, national, and provincial laws. It is crucial to delve further into this question, not merely in the case of mixed-status families, ${ }^{57}$ but rather in all cases where children are involved and where they risk being disadvantaged as a result of their parents' or their own legal status. Furthermore, this study sheds light on the financial, social, and emotional burdens experienced by individuals and families living with precarious legal status in Canada. In particular, fear and isolation both play a role in people's ability and willingness to access services such as health care and education. Notions of status and access to services become complicated, as fear and lack of information (or misinformation) blur lines drawn around rights and entitlements.

It is important to recognize that there is a distinction between inability to access services or claim rights and unwillingness to do so, yet this distinction is not always clear to individuals living with uncertain status or to the service providers and practitioners who work with them. The resulting uncertainty is likely to lead to inequitable access and differential outcomes. This unevenness has important implications for service providers and practitioners, including settlement workers, teachers, and health-care providers: these individuals ought to be aware that the families they work with may be in precarious situations and fearful of accessing services for themselves and for their children, or to participate in programs. We emphasize here that the legal rights of the children of people with precarious status are, in many respects, quite clear, at least on paper. Hence it is a matter of our society implementing the necessary means to arrive at policy objectives which are already agreed upon and in legislation. All service providers and educators need to make greater efforts to help give these children the life in Canada to which they are entitled.

\section{Appendix A: Socio-Demographic Profile}

\begin{tabular}{|l|c|c||}
\hline \multicolumn{1}{|c|}{ Area } & Number & Percentage \\
\hline \hline Status Upon Entry to Canada & + \\
\hline Tourist visa & 9 & $60 \%$ \\
\hline Refugee claimant & 3 & $20 \%$ \\
\hline Missing data & 3 & $20 \%$ \\
\hline Current status (at time of interview) & \\
\hline $\begin{array}{l}\text { Awaiting outcome of } \\
\text { refugee claim }\end{array}$ & 3 & $20 \%$ \\
\hline $\begin{array}{l}\text { Awaiting outcome of H\&C } \\
\text { or appeal }\end{array}$ & 7 & $46.6 \%$ \\
\hline $\begin{array}{l}\text { Denied refugee claimant } \\
\text { (1 with deportation order) }\end{array}$ & 3 & $20,0 \%$ \\
\hline \begin{tabular}{l} 
Visa overstayer \\
\hline
\end{tabular} & 2 & $13.3 \%$ \\
\hline
\end{tabular}




\section{Notes}

1. In recent years, media coverage has begun to draw attention to the presence of persons living without status in Canada (Marina Jimenez, “200,000 Illegal Immigrants Toiling in Canada's Underground Economy," Globe and Mail, November 15, 2003; Nicholas Keung, "Hope Fades for Plan to Aid Illegal Workers: Illegal Workers Fear Effect of Election," Toronto Star, May 16, 2005; Maureen Murray, "Hopes, Dreams but No Status: Illegals Meet to Share Stories," Toronto Star, November 15, 2003; Grant Robertson, "Canada Has No Handle on Illegal Immigrant Workers," Edmonton Journal, May 30, 2005; Isabel Teotonio, "Working in the Shadows," Toronto Star, March 25, 2006.). However, it has been difficult to get an idea of the precise size of this population as there are no census data or reliable published sources providing accurate counts. Estimates have ranged from 200,000 (Peter Cheney and Colin Freeze, "200,000 May Be in Canada Illegally: Economic Underclass Faces Bleak Future, But Now Everyone Supports Amnesty," Globe and Mail, May 26, 2001) to 400,000 "underground workers" (Robertson). Possible regularization programs have also been discussed, although their implementation at this time seems, due to recent changes in the federal government, particularly unlikely (CTV, "Panel Discussion on Immigration Amnesty Program," CTV Sunday Edition, CTV Television Network, 1994); Keung; Status Campaign, "NonStatus Immigrants: Not So Underground, Not So Visible," $<$ http://www.ocasi.org/status/index.asp > (accessed December 20, 2006).

2. This paper reports on findings from a pilot study carried out as part of a Social Sciences and Humanities Research Council developmental grant under the Community-University Research Alliance funding program. This community-university partnership involved representatives from Access Alliance Multicultural Community Health Centre, Community Legal Education Ontario, Community Social Planning Council of Toronto, Davenport-Perth Neighbourhood Centre, FCJ Refugee Centre, Folk Arts Council of St. Catharines, Hospital for Sick Children (Community Health Systems Resource Group), Laidlaw Foundation, London Cross Cultural Learner Centre, Metro Toronto Chinese and Southeast Asian Legal Clinic, New Canadians' Centre of Excellence, Ontario Council of Agencies Serving Immigrants, Ryerson University, and York University.

3. Carolina Berinstein, Jean McDonald, Peter Nyers, Cynthia Wright, and Sima Zerehi, "Access Not Fear": Non-Status Immigrants and City Services (2006), <http://www.dadttoronto.org/members/publications/Access $\% 20$ Not $\% 20$ Fear\%20Report\%20(Feb\%202006).pdf> (accessed April 19, 2006); Status Campaign.

4. Luin Goldring, Carolina Berinstein, and Judith Bernhard, "Institutionalizing Pathways to Precarious Legal Status in Canada" (unpublished, 2007), based on Luin Goldring and Carolina Berinstein, "More and Less Legal: Bringing Legal Status and Rights into the Open in Canada" (presented at
Migration and Integration in the Americas, annual conference of the Centre for Research on Latin America and the Caribbean, York University, Toronto, September 19-20, 2003).

5. Ibid.

6 Examples of categories of uncertain status situations include: (1) denied refugee claimants; (2) approved Convention Refugees who did not apply for landing within the required 180-day limit; (3) persons with work permit breakdown; (4) expired visa holders; (5) persons with sponsorship breakdown; (6) refused Humanitarian and Compassionate ( $\mathrm{H} \& \mathrm{C}$ ) applicants; (7) persons refused by various other programs. This list is not exhaustive, as people can move into uncertain status through various means, including changes in administrative procedures. See Goldring, Berinstein, and Bernhard for more detail. The situation of refugee claimants and asylum seekers is a case in point. After the December 2004 implementation of the Safe Third Country Agreement, claimants from other countries who had stopped in the United States or another country considered to be "safe" became ineligible to apply for refuge in Canada. At the same time, opportunities for making inland claims were limited severely. This affected many potential claimants already in Canada, as well as those in the United States but on their way to Canada. See CBC News, "Refugee Claims Down 40\% in Deal's Wake," (July 27, 2005), $<$ http://www.cbc.ca/story/canada/national/2005/07/27/refu gee-claims050727.html>.

7. Susan Rees, "Refuge or Re-trauma? The Impact of Asylum Seeker Status on the Wellbeing of East Timorese Women Asylum Seekers Living in the Australian Community," Australasian Psychiatry 11 (2003): 98.

8. Access Alliance Multicultural Community Health Centre, $R a-$ cialised Groups and Health Status: A Literature Review Exploring Poverty, Housing, Race-Based Discrimination and Access to Health Care as Determinants of Health for Racialised Groups (Toronto: Access Alliance Multicultural Community Health Centre, 2005); Dennis Raphael, Social Determinants of Health: Canadian Perspectives (Toronto: Canadian Scholars' Press, 2004).

9. Goldring, Berinstein, and Bernhard; Rees; Carola SuarezOrozco and Desiree Baolian Qin, "Gendered Perspectives in Psychology: Immigrant Origin Youth,” International Migration Review 40 (2006): 165-198; Helen Schwenken, "For All: The Political Self-Organization of Female Migrant Domestic Workers in the European Union," Refuge 21 (2003): 45-52.

10. Denise Gastaldo, Gavin Andrews, and Nazilla Khanlou, "Therapeutic Landscapes of the Mind: Theorizing Some Intersections between Health Geography, Health Promotion and Immigration Studies," Critical Public Health 14 (2004):162.

11. Morley Beiser and Feng Hou, "Ethnic Identity, Resettlement Stress and Depressive Affect among Southeast Asian Refugees in Canada," Social Science and Medicine 63 (2006): 138.

12. Leo Chavez, Shadowed Lives: Undocumented Immigrants in American Society, $2^{\text {nd }}$ ed. (Toronto: Harcourt Brace College 
Publishers, 1998); Gastaldo, Andrews, and Khanlou; Jessica Goodkind, "Promoting Hmong Refugees' Well-Being through Mutual Learning: Valuing Knowledge, Culture and Experience," American Journal of Community Psychology 37 (2006): 77-93; Suarez-Orozco and Qin; Anne-Marie Wallin and Gerd Ahlström, "Unaccompanied Young Adult Refugees in Sweden, Experiences of Their Life Situation and Well-Being: A Qualitative Follow-up Study," Ethnicity and Health 10 (2005): 129-144.

13. Luin Goldring, "Blurring Borders: Constructing Transnational Community in the Process of Mexico-U.S. Migration," Research in Community Sociology 6 (1996): 69-104; Luin Goldring, "The Power of Status in Transnational Social Fields," Comparative Urban and Community Research 6 (1998): 165-195; Patricia Landolt, "Building Communities in Transnational Social Fields: The Case of Salvadoran Refugees, Migrants and Returnees," Estudios Migratorios Latinoamericanos 17 (2004): 627-650.

14. Goldring, Berinstein, and Bernhard; Elsy Jetty Chakkalakal and Alex Neve, "Living Without Status in Canada: Human Rights Underground” (Human Rights Underground Conference, Toronto, 1998); Patricia Landolt, "The Institutional Landscapes of Salvadoran Refugee Migration: Transnational and Local Views from Los Angeles and Toronto," in Organizing the Transnational: The Experience of Asian and Latin American Migrants in Canada, ed. L. Goldring and S. V. Krishnamurti (Vancouver: University of British Columbia Press, 2007); Parkdale Community Legal Services and Vigil Toronto, Final Report to the Trillium Foundation for Documenting the Undocumented, Living Without Status: Human Rights Underground (Toronto: Parkdale Community Legal Services, 1999); R. Magaly San Martin, "Unwanted in Paradise: Undocumented Migrant Women Sex-Workers in Toronto," in Calculated Kindness: Global Restructuring, Immigration and Settlement in Canada, ed. R. B. Folson (Black Point: Fernwood Publishing, 2004); M. Y. Tam and A. Alfred, People without Status in Canada: What Do We Know? Where Do We Go from Here? (Toronto: Faculty of Social Work, University of Toronto, 2003); Sarah Wayland, Unsettled: Legal and Policy Barriers for Newcomers to Canada (Ottawa: Community Foundations of Canada and Law Commission of Canada, 2006).

15. Berinstein, McDonald, Nyers, Wright, and Zerehi.

16. M. Bannerman, P. Hoa, and R Male, South Riverdale Community Health Centre's Exploration of Services for Non-Insured People in East Toronto (Toronto: South Riverdale Community Health Centre, 2003); Berinstein, McDonald, Nyers, Wright, and Zerehi; Committee for Accessible AIDS Treatment (CAAT), Improving Access to Legal Services and Health Care for People Living with HIV/AIDS who are Immigrants, Refugees or Without Status (Toronto: Regent Park Community Health Centre, 2001); Community Legal Education Ontario, Every Child's Legal Right to Education (Toronto: Parkdale Community Legal Services), <http://www.cleo.on.ca/english/pub/onpub/PDF/immigration/ev chlde d.pdf $>$; Wayland; Maria Yau,
Refugee Students in Toronto Schools: An Exploratory Study (Toronto: Toronto Board of Education, Research Services, 1995).

17. In studies of immigrant families, for example, it is often possible to discern examples of children and parents with uncertain legal status even though the investigators may have stayed away from explicit questions about immigration status. These examples occur in several studies that examine the experiences of immigrant and refugee children and families in both Canada and the US: Judith K. Bernhard and Marlinda Freire, "Caring For and Teaching Children of Refugee Families," in Include Me Too: Human Diversity in Early Childhood, ed. K. M. Kilbride (Toronto: Harcourt Brace, 1997); Ana Marie Fantino and Alice Colak, "Refugee Children in Canada: Searching for Identity," Child Welfare 80 (2001) 587-596; Kenise M. Kilbride, Paul Anisef, Etta Baichman-Anisef, and Rhanda Khattar, Between Two Worlds: The Experiences and Concerns of Immigrant Youth in Ontario (Toronto: Joint Centre of Excellence for Research on Immigration and Settlement, 2000); Marjorie F. Orellana, Barrie Thorne, Anne Chee, and Wan Shun E. Lam, "Transnational Childhoods: The Participation of Children in Processes of Family Migration," Social Problems 48 (2001): 572-591; Ruben G. Rumbaut and Alejandro Portes, Ethnicities: Children of Immigrants in America (New York: Russell Sage Foundation, 2001); Carola SuarezOrozco and Marcelo Suarez-Orozco, Children of Immigration (Cambridge, MA: Harvard University Press, 2001).

18. John Lowman and Ted Palys, "Ethics and Institutional Conflict of Interest: The Research Confidentiality Controversy at Simon Fraser University," Sociological Practice 2 (2000): 245-264.

19. Peter Gorrie, "Tories Begin Deporting Illegal Workers," Toronto Star, March 21, 2006.

20. Margaret E. Martin et al., "Report of the ASA Technical Panel on the Census Undercount," American Statistician 38 (1984): 252-256; Jeffrey S. Passel, "Undocumented Immigration," Annals of the American Academy of Political and Social Science 487 (1986): 181-200.

21. Frank D. Bean et al., "Circular, Invisible, and Ambiguous Migrants: Components of Difference in Estimates of the Number of Unauthorized Mexican Migrants in the United States," Demography 38 (2001): 411-422; Marc Berk and Claudia Schur, "The Effect of Fear on Access to Care among Undocumented Latino Immigrants," Journal of Immigrant Health 3 (2001): 151-156; Chavez, Shadowed Lives; Wayne Cornelius, "Interviewing Undocumented Immigrants: Methodological Reflections Based on Fieldwork in Mexico and the US," International Migration Review 16 (1982): 378-411; Passel.

22. Berinstein, McDonald, Nyers, Wright,and Zerehi; Chakkalakal and Neve; Community Legal Education Ontario, Every Child's Legal Right to Education; Wayland.

23. Berk and Schur, Chavez, Shadowed Lives; Michael Fix and Wendy Zimmermann, All Under One Roof: Mixed-Status 
Families in an Era of Reform (Washington, D.C.: Urban Institute, 1999); Gabrielle Lessard and Leighton $\mathrm{Ku}$, "Gaps in Coverage for Children in Immigrant Families," The Future of Children 13 (2003): 100-115; Carola Suarez-Orozco and Marcelo Suarez-Orozco, Children of Immigration (Cambridge, MA: Harvard University Press, 2001).

24. Leo Chavez, "The Power of the Imagined Community: The Settlement of Undocumented Mexicans and Central Americans in the United States," American Anthropologist 96 (1994): 68.

25. Rees.

26. Cecillia Menjívar, "Liminal Legality: Salvadoran and Guatemalan Immigrants' Lives in the United States," American Journal of Sociology 111 (2006): 1030.

27. Committee for Accessible AIDS Treatment (CAAT); Fix and Zimmermann; Suarez-Orozco and Suarez-Orozco; Wayland.

28. Trevor Marshall, Citizenship and Social Class (New York: Cambridge University Press, 1950).

29. Alison Brysk, "Children across Borders: Patrimony, Property, or Persons?," in People Out of Place: Globalization, Human Rights, and the Citizenship Gap, ed. Alison Brysk and Gershon Shafir (New York: Routledge, 2004).

30. Julie Young, "This is my life': Questions of Agency and Belonging among Youth Living with Less than Full Status" (master's major research paper, Ryerson University, Toronto, 2005).

31. Note that the LISA researchers did not explicitly ask about uncertain status, but instead they were able to discern this status through the interactions they had with families throughout the duration of the project and through responses to particular questions. For example, if the question was, "What was the most difficult part of the immigration process?" and the response was, "Crossing the border," it was probable that this child was undocumented at some point (Suarez-Orozco and Suarez-Orozco).

32. Suarez-Orozco and Suarez-Orozco.

33. Committee for Accessible AIDS Treatment (CAAT); Jimenez; Ratna Omidvar and Ted Richmond, Perspectives on Social Inclusion: Immigrant Settlement and Social Inclusion in Canada (Toronto: Laidlaw Foundation, 2003); Wayland.

34. City of Toronto, Subsidized Childcare: How Do I Apply for a Fee Subsidy? (Toronto: City of Toronto), <http://www.city. toronto.on.ca/children/subsidy.htm>; Martha Friendly and Donna Lero, Social Inclusion through Early Childhood Education (Guelph: Laidlaw Foundation, 2002), <http://www.laidlawfdn.org/cms/file/children/lero.pdf $>$ (accessed January 7, 2007).

35. In order to qualify for this benefit, the applicant or their spouse or common-law partner must be "a Canadian citizen, a permanent resident, a protected person, or a temporary resident who has lived in Canada for the previous 18 months" (Canada Revenue Agency, 2005).
36. Cheryl Teelucksing, Luin Goldring, and Judith Bernhard, Survey of Agencies Serving Persons with Less Than Full Status. (Toronto: Ryerson University, 2005).

37. Fix and Zimmermann.

38. Young.

39. Teelucksing, Goldring, and Bernhard.

40. The agency personnel screened potential participants and retained all identifying information, which never appeared in the researchers' records. Participants gave verbal (rather than written) consent and were clearly informed that they were free to withdraw at any time during the process. In addition, they were asked to give double consent to participate: first to the community service providers who recruited them, and second to the researcher who carried out the interview. The service provider made clear that whether or not an individual chose to participate in the study, her/his access to services at the organization would not be affected. Moreover, the double consent process ensured that service providers would not know who did or did not choose to participate in the project.

41. This group includes one woman whose grown daughter, over age thirty, lived in Canada. Note that participants may be counted under more than one of these categories.

42. This group includes one woman with two children over age twenty-five.

43. All names used are pseudonyms.

44. Section 30(2) of the Immigration and Refugee Protection Act (IRPA) states: "Every minor child in Canada, other than a child of a temporary resident not authorized to work or study, is authorized to study at the pre-school, primary or secondary level." In Ontario, children of temporary residents may be permitted to attend school but they are required to pay international student fees in the range of Can. $\$ 7,000$ to10,000 per year, which is a barrier for many families; this fee has been waived for children whose parents have submitted an application for permanent residence (Community Legal Education Ontario, Every Child's Legal Right to Education; Government of Canada, Immigration and Refugee Protection Act (2001), $<$ http://laws.justice.gc.ca/en/I-2.5/64755.html> (accessed June 10, 2006); Government of Ontario, Educational Act (1990), <http://www.elaws.gov.on.ca/DBLaws/Statutes/English/90e02_e.htm>. (accessed April 19, 2006).

45. United Nations, Convention on the Rights of the Child (1990), $<$ http://www.unicef.org/crc/crc.htm> (accessed April 19, 2006).

46. Young.

47. Suarez-Orozco and Suarez-Orozco. .

48. Menjívar; Goldring, Berinstein, and Bernhard

49. Rees.

50. Judith Bernhard, Patricia Landolt, and Luin Goldring, Transnational, Multi-Local Motherhood: Experiences of Separation and Reunification among Latin American Families in Canada (Toronto: Joint Centre of Excellence for Research on Immigration and Settlement, 2005). 
51. Teelucksing, Goldring, and Bernhard.

52. Berinstein, McDonald, Nyers, Wright, and Zerehi; Wayland.

53. Menjívar; Rees; Wayland.

54. Young.

55. United Nations, Convention on the Rights of the Child.

56. Fix and Zimmermann.

57. Ibid.

Judith K. Bernhard is Professor at the School of Early Childhood Education at Ryerson University. Luin Goldring is Associate Professor of Sociology at York University. Julie Young is a Ph.D. student in the Department of Geography at York University. Carolina Berinstein works with the Access Alliance Multicultural Community Health Centre. Beth Wilson is a researcher with the Community Social Planning Council of Toronto. 